\title{
Needs A ssessment Kompetensi Pelengkap Mahasiswa Pendidikan Islam Anak Usia Dini Berdasarkan Kebutuhan Pengguna
}

\author{
Nurlaeli Fitriah
}

Received: 2922017 / Accepted: 2032017 / Published online: 1362017

๑ 2017 Association of Indonesian Islamic Kindergarten Teachers Education Study Program

\begin{abstract}
The purpose of this study is to identifying competences of students of Department of Pendidikan Guru Raudhatul Athfal in Tarbiyah and Teaching Faculty UIN M aulana M alik I brahim M alang that needed by users. This study using needs assessment approach for finding competences of student that needed by users. This study used a quantitative approach and the type of this study was a survey research (quantitative descriptive). Data was collected by using questionnaires and interviews. The result of this study are competences that need to be owned by the students based on priority needs. They are as follows: (1) Factor 1 consist of skills related to the skills intra-personal namely control emotions, affection, self confidence, work hardly, motivation, discipline, never surrender, diligent, initiative, creativity, adaptability, ability of IT, (2) Factor 2 consist of skills related to the skills of interpersonal namely the ability of Arabic, teamwork, ability of english, proficiency, leading a team, written communication, public speaking, verbal communication; (3) Factor 3 consists of skill related to technical skill that are praktik ibadah, hafalan surat pendek, skill of arts, baca tulis alQur'an, skill of music, skill of dancing, doa-doa harian.
\end{abstract}

Keywords: needs assessment, competences of student, users.

\begin{abstract}
Abstrak Tujuan penelitian ini adalah untuk mengidentifikasi kompetensi mahasiswa Jurusan Pendidikan Islam Anak Usia Dini di Tarbiyah dan Fakultas UIN Maulana Malik $M$ alang yang dibutuhkan oleh pengguna. Penelitian ini menggunakan pendekatan penilaian kebutuhan untuk menemukan kompetensi siswa yang dibutuhkan oleh pengguna. Penelitian ini menggunakan pendekatan kuantitatif, dan strategi yang dipilih adalah survey. Data dikumpulkan dengan menggunakan kuesioner dan wawancara. Hasil penelitian ini adalah kompetensi yang harus dimiliki oleh mahasiswa berdasarkan kebutuhan prioritas, sebagai berikut: (1) Faktor 1 terdiri dari keterampilan yang berkaitan dengan keterampilan intra personal yaitu pengendalian diri, kasih sayang, kepercayaan diri, bekerja keras, motivasi, disiplin, tidak menyerah, rajin, inisiatif, kemampuan beradaptasi, kemampuan IT, (2) Faktor 2 terdiri dari keterampilan yang berhubungan dengan keterampilan interpersonal yaitu kemampuan bahasa Arab, kerja tim, kemampuan bahasa Inggris, kemahiran, memimpin tim, komunikasi tertulis, komunikasi lisan, komunikasi verbal, (3) Faktor 3 terdiri dari keterampilan yang berkaitan dengan keterampilan teknis yaitu praktik ibadah, hafalan surat pendek, keterampilan seni, baca tulis al-Qur'an, keterampilan musik dan suara, doa- doa harian
\end{abstract}

Kata kunci: analisis kebutuhan, kompetensi mahasiswa, pengguna. 


\section{Pendahuluan}

A nak merupakan individu unik yang jelas berbeda dengan orang dewasa. Dengan bentuk fisik yang sama namun dengan ukuran dan kematangan pertumbuhan yang berbeda menjadikan anak sebagai individu dengan spesialisasi tersendiri. Spesialisasi tersendiri disini dimaknai sebagai segala hal yang berhubungan dengan penanganan terhadap anak menjadi sebuah konsentrasi tersendiri. Banyak contoh penanganan terhadap anak yang tidak bisa disamakan dengan orang dewasa seperti salah satunya dalam hal kesehatan. U ntuk penanganan kesehatan terhadap anak dalam dunia medis ditangani oleh dokter spesialis anak. Demikian pula dalam hal pendidikan khususnya pendidikan anak usia dini. Dalam hal perkembangan anak usia dini, penting untuk dipikirkan hal-hal yang berkaitan dengan optimalisasi penanganannya. Karena anak usia dini adalah generasi yang akan menentukan baik buruknya kehidupan di masa yang akan datang. Tidak hanya dalam hal perkembangan secara fisik juga dalam hal mental dan spiritualnya. Oleh karena itu diperlukan asuhan dan didikan yang benar dan tepat agar dapat memaksimalkan perkembangan dan potensi mereka. Sederhananya, menangani anak bukan seperti menangani orang dewasa dalam "versi kecil".

Namun demikian untuk mencetak seorang pendidik yang memahami tentang anak usia dini dan perkembangannya membutuhkan kurikulum yang dapat menghasilkan lulusan yang memiliki kompetensi sebagai pendidik bagi anak usia dini. Kompetensi apa saja yang perlu dimiliki oleh seorang lulusan PIAUD agar dapat menjalankan profesinya dengan sebaik-baiknya sesuai dengan kebutuhan anak usia dini berdasarkan perspektif keilmuan maupun kebutuhan masyarakat.

Artikel ini membahas kebutuhan Jurusan Pendidikan Islam Anak Usia Dini di Fakultas IImu Tarbiyah dan Keguruan UIN Maulana Malik Ibrahim Malang untuk melengkapi lulusannya dengan berbagai kompetensi tambahan dengan menggunakan needs assessment approach berbasis kebutuhan masyarakat pengguna. Dengan demikian artikel ini dapat menambah referensi dan melengkapi needs assessment yang dilakukan secara kualitatif.

\section{Needs assessment dalam Penelitian}

A nalisis kebutuhan merupakan satu alat yang tepat sebagai pelengkap bagi evaluator program ketika mempertimbangkan kejelasan masalah, serta memberikan rekomendasi kepada penentu kebijakan. Atas dasar uraian tersebut para evaluator perlu memahami dengan tepat apa, mengapa, dan bagaimana melakukan analisis kebutuhan.

Needs assessment merupakan bagian dari model penelitian evaluasi. Pendekatan yang dapat digunakan dalam penelitian needs assessment ini adalah pendekatan kuantitatif. Dalam kegiatan analisis kebutuhan terdapat adanya proses mengenali, memilah dan menyisihkan, sehingga melalui proses tersebut seorang peneliti pastinya akan berkutat dengan aktivitas mengukur dan menilai. Untuk mengetahui hasil mengenali, memilah dan menyisihkan, diperlukan proses membandingkan gejala yang sedang dikenali dan dipilah berdasarkan kriteria tertentu.

M enurut Guyette (1983) ada dua cara melakukan needs assessment melalui pendekatan deduktif dan pendekatan induktif. Dalam pendekatan deduktif, pertanyaan-pertanyaan yang dilakukan adalah "Apa tujuan yang kita inginkan?", "Dimana hubungan kita dengan tujuan tersebut". Ada empat langkah dalam pendekatan ini, yaitu; (1) Mendaftar tujuan dan diperingkat berdasarkan kepentingannya; (2) Menentukan tujuan berdasarkan kondisi saat ini; 
(3) M engidentifikasi kesenjangan/perbedaan antara tujuan dan kondisi saat ini; dan (4) Prioritas kondisi (tingkat kebutuhan dan sumber daya) yang diinginkan didokumentasikan.

A dapun dalam pendekatan induktif, pertanyaan-pertanyaan adalah "Dimana kita?" dan kemudian "Apa yang kita inginkan?" Langkah-langkahnya secara umum adalah (1) M enggambarkan kondisi dan membuat instrumen untuk penilaian; (2) M enentukan status saat ini berdasarkan tujuan dan kondisi sebelumnya; (3) Mengidentifikasi dan menganalisis perbedaan antara tujuan sebelumnya dan keadaan sekarang; dan (4) Menetapkan prioritas berdasarkan perbedaan, sehingga dapat ditentukan tujuan baru.

Sedangkan menurut Anderson (1975) (dalam A rikunto, 2010) secara umum keluasan dan besarnya kebutuhan dapat diukur secara subjektif dan objektif. Penilaian kebutuhan secara subjektif terjadi bila pelaku membandingkan sesuatu kebutuhan dengan kondisi yang dapat diterima olehnya, antara lain: (1) mengidentifikasi lingkup tujuan-tujuan penting dalam rogram yang akan dievaluasi; (2) menentukan indikator dan cara pengukuran tujuan-tujuan; (3) menyusun kriteria (standar) untuk tiap-tiap indikator, dengan tujuan pedoman atau acuan apa saja yang ada dalam sistem dan bidang yang dievaluasi; (4) menyusun alat pengukuran untuk tiap-tiap indikator; dan (5) membandingkan kondisi yang diperoleh dengan kriteria. Jika data yang diperoleh lebih rendah dari tingkat standar, maknanya berarti ada kebutuhan.

Penilaian kebutuhan secara objektif terjadi bila kebutuhan yang diukur itu dibandingkan dengan besarnya kebutuhan sesuatu bidang yang terkait dan sesuai bidang yang akan dievaluasi, antara lain: (1) mengidentifikasi tujuan penting dalam program yang akan dievaluasi; (2) menentukan kriteria atau menyusun kriteria yang sesuai dengan tujuan masing-masing bidang atau indikator. Dalam langkah ini evaluator perlu mengumpulkan banak bukti formal yang akan digunakan untuk dasar pertimbangan kebutuhan. (3) Menyusun peringkat yang digunakan untuk mempertimbangkan tingkat penampilan indikator. Dalam pembuatan skala sedapat mungkin diurutkan sesuai dengan tingkat penerimaan (dari 5 ke 1 - jika menggunakan skala 5 , atau 4 ke 1 - jika menggunakan skla 4, dan seterusnya). Skala tersebut seyogyanya berbentuk interval. (4) Jika sudah selesai membuat skala, kumpulkan semua calon evaluator untuk bersama-sama menentukan urutan kebutuhan dan skala prioritas kebutuhan. Jika kebutuhan terdapat dua kebutuhan yang sejajar, diperlukan lagi kesepakatan untuk menentukan mana kebutuhan yang lebih mendesak untuk diprioritaskan dalam penyelesaiannya. Penting diingat: dalam menentukan urutan kebutuhan jangan sampai ada unsur subjektivitas, yang dapat menyebabkan hasilnya menyimpang dari kenyataan.

Selain memilih kedua cara tersebut, evaluator dapat mengambil nominasi dari keduanya. Seorang penilai mungkin saja mengambil langkah yang berbeda dari waktu ke waktu dan dari satu situasi ke situasi yang lain. Oleh karena itu, data dari pihak lain (mungkin pendapat teman/lawan), catatan yang dibuat siswa dan sebagainya dapat dijadikan bahan pertimbangan. Data-data tambahan tidak boleh diambil sembarangan, tetapi harus dilihat taraf keterandalannya.

Pertimbangan yang dilakukan untuk menentukan jenis serta peringkat kebutuhan menggunakan bukti formal, dengan kasus yang berbeda. A papun pendekatan yang diambil, langkah selanjutnya menentukan prioritas antar kebutuhan sesuai tujuan, yang selanjutnya digunakan untuk menentukan rekomendasi kepada pengambil keputusan demi tindak lanjut program. Perlu diingatkan bahwa evaluator tidak mempunyai hak untuk mengambil keputusan tentang program, tetapi hanya memberian rekomendasi, selanjutnya pengambil keputusanlah yang menentukan lebih lanjut. 


\section{Kompetensi Guru RA}

Permendiknas Nomor 16 tahun 2007 menyatakan bahwa Guru pada PAUD/TK/RA harus memiliki kualifikasi akademik pendidikan minimum diploma empat (D-IV) atau sarjana (S1) dalam bidang pendidikan anak usia dini atau psikologi yang diperoleh dari program studi yang terakreditasi. Sedangkan kompetensi yang harus dimiliki oleh seorang guru pada PAUD/TK/RA sebagaimana permendiknas tersebut adalah kompetensi pedagogik, kompetensi kepribadian, kompetensi social dan kompetensi profesional. Pemenuhan kompetensi tersebut di atas adalah sudah menjadi tuntutan yang harus dimiliki oleh seorang guru apapun jenjang pendidikan yang nanti akan menjadi wilayah pengajarannya. Dan hal itu sudah menjadi bagian dari kurikulum fakultas keguruan.

Penyelenggaraan program Studi Pendidikan Guru Raudhatul Athfal di Fakultas IImu Tarbiyah dan Keguruan UIN M aulana M alik Ibrahim M alang, memberikan harapan yang besar bagi ribuan lembaga pendidikan anak usia dini baik yang formal maupun yang non formal di Kota Malang yang minim guru dengan kualifikasi dan kompetensi sebagai pendidik PAUD. Karena itulah, sebagai prodi yang masih relatif baru sudah semestinya program studi PGRA diarahkan pada pencapaian sasaran kompetensi sebagai guru RA. Oleh karena itu, untuk memenuhi harapan tersebut tentunya program studi PGRA sejak dini harus mempersiapkan para lulusannya nanti dapat diterima dan sesuai dengan yang dibutuhkan masyarakat dan memiliki ciri khas tersendiri secara kelembagaan.

\section{Kompetensi yang Dibutuhkan D unia Kerja}

IImu pengetahuan dan teknologi berkembang dengan sangat cepat disertai dengan dinamika kehidupan yang menuntut kita untuk terus membuka mata akan perubahan-perubahan yang terjadi terutama di lingkungan kerja. Tantangan-tantangan serta tuntutan-tuntutan yang muncul di dunia kerja yang didorong oleh semakin kompetitifnya posisi-posisi dalam dunia kerja yang diinginkan tentunya membutuhkan perhatian bagi pihak-pihak yang berkepentingan dan berkaitan. Demikian pula halnya dengan perguruan tinggi sebagai pencetak tenaga kerja.

Demi menjawab tantangan di era kompetisi ini, perguruan tinggi sebagai lembaga pencetak tenaga kerja hendaknya selalu mengantisipasi segala dinamika yang ada di lapangan melalui upaya-upaya evaluasi untuk menghasilkan lulusan-lulusan yang memiliki kemampuan yang sesuai dengan yang dibutuhkan di lingkungan kerja.

Yorke dan Knight (2003:4) mengenalkan konsep "employability" atau kemampuan bekerja yang didefinisikan sebagai sekumpulan pencapaian (achievement) meliputi keterampilan, pemahaman, dan atribut personal yang lebih memungkinan lulusan untuk memperoleh pekerjaan dan sukses dalam pilihan kerjanya serta memberi keuntungan bagi diri mereka sendiri, tenaga kerja, masyarakat, dan ekonomi secara keseluruhan.

Seorang lulusan akan mendapatkan kesempatan yang lebih besar jika memiliki kemampuan bekerja sebagaimana didefinisikan di atas. Bisa dikatakan bahwa untuk dapat berkompetisi di dunia kerja, seorang lulusan tidak cukup dengan hanya sekedar pintar atau cerdas saja secara kognitif tetapi juga dibutuhkan dimensi lainnya yang meliputi ketrampilan dan atribut personal lainnya yang memudahkannya berhubungan dengan orang lain di sekitarnya.

Ada 3 kompetensi yang mengantarkan kesuksesan yaitu: (1) kompetensi profesional (hard skill), (2) kompetensi softskill intra personal, (3) kompetensi softskill interpersonal (Zaman \& Solichin, 2015). Ketiga kompetensi ini dikenal sebagai kecerdasan intelektual dan 
kecerdasan emosional di mana ketiganya dibutuhkan dalam dunia kerja. Kompetensi profesional (hard skill) kebanyakan dalam kurikulum pendidikan di lembaga pendidikan tinggi telah tercantum secara eksplisit dalam bentuk mata kuliah. Namun untuk pengembangan kompetensi softskill kebanyakan sulit untuk diimpementasikan dalam bentuk mata kuliah. Memang ada beberapa mata kuliah yang bisa dimunculkan untuk mengembangkan soft skill mahasiswa seperti etika profesi, namun kebanyakan memang mata kuliah yang ada dalam kurikulum adalah untuk pengembangan kompetensi soft skill.

\section{Metode Penelitian}

Pendekatan yang akan digunakan dalam penelitian ini adalah pendekatan kuantitatif dengan jenis penelitian survei. Pengumpulan data dilakukan dengan menggunakan kuesioner dan wawancara. Wawancara digunakan untuk memperoleh informasi dari beberapa guru RA/BA/TA/TK yang terkait dengan penelitian sedangkan kuesioner digunakan untuk memperoleh data kuantitatif yang akan diolah yang terkait dengan kebutuhan kompetensi pelengkap bagi Iulusan PGRA UIN Maulana Malik Ibrahim Malang. Sistem penilaian skala analisis kebutuhan kompetensi pelengkap lulusan PGRA didasarkan pada modifikasi skala Likert dengan menggunakan empat alternatif jawaban yang meliputi jawaban yang Sangat dibutuhkan (4), Dibutuhkan (3), Cukup dibutuhkan (2) dan Tidak dibutuhkan (1).

Sebagai persyaratan kelayakan instrumen, kuesioner yang telah tersusun diuji tingkat validitas dan reliabilitasnya sehingga diperoleh hasil sebagai berikut:

Tabel 1

\begin{tabular}{|c|c|}
\hline \multicolumn{2}{|c|}{ Reliability Statistics } \\
\hline $\begin{array}{c}\text { Cronbach's } \\
\text { Alpha }\end{array}$ & N of Items \\
\hline .930 & 30 \\
\hline
\end{tabular}

Tabel 2

Tingkat $V$ aliditas

\begin{tabular}{|l|c|c|c|}
\hline \multicolumn{1}{|c|}{ Item } & $r$ & Kriteria & Predikat \\
\hline H afalan Surat Pendek & 0.639 & 0.300 & Valid \\
\hline Baca Tulis Alqur'an & 0.682 & 0.300 & Valid \\
\hline Ibadah & 0.650 & 0.300 & Valid \\
\hline Doa H arian & 0.388 & 0.300 & Valid \\
\hline Ketrampilan Seni & 0.873 & 0.300 & Valid \\
\hline Ketrampilan Seni Suara dan M usik & 0.790 & 0.300 & Valid \\
\hline Rupa Ketrampilan Seni Tari & 0.833 & 0.300 & Valid \\
\hline Komunikasi Verbal & 0.730 & 0.300 & Valid \\
\hline Kemampuan Bahasa Inggris & 0.511 & 0.300 & Valid \\
\hline Kemampuan Bahasa Arab & 0.572 & 0.300 & Valid \\
\hline Komunikasi Tertulis & 0.640 & 0.300 & Valid \\
\hline M emimpin Tim & 0.771 & 0.300 & Valid \\
\hline Teamwork & 0.514 & 0.300 & Valid \\
\hline Publik Speaking & 0.565 & 0.300 & Valid \\
\hline Kemampuan IT & 0.480 & 0.300 & Valid \\
\hline Kemampuan adaptasi & 0.446 & 0.300 & Valid \\
\hline Kreativitas & 0.697 & 0.300 & Valid \\
\hline
\end{tabular}




\begin{tabular}{|l|l|l|l|}
\hline Pengendalian Emosi & 0.677 & 0.300 & Valid \\
\hline M enunjukkan Kasih Sayang & 0.350 & 0.300 & Valid \\
\hline Pantang M enyerah & 0.685 & 0.300 & Valid \\
\hline Percaya Diri & 0.366 & 0.300 & Valid \\
\hline Disiplin & 0.496 & 0.300 & Valid \\
\hline Inisiatif & 0.627 & 0.300 & Valid \\
\hline Bekerja Keras & 0.642 & 0.300 & Valid \\
\hline M otivasi & 0.650 & 0.300 & Valid \\
\hline Tekun & 0.625 & 0.300 & Valid \\
\hline
\end{tabular}

Uji validitas dilakukan dengan membandingkan nilai koefisien korelasi hitung ( $r_{\text {hitung }}$ ) dengan nilai koefisien korelasi tabel $\left(r_{\text {tabel }}\right)$. Jika $r_{\text {hitung }}$ lebih besar dibandingkan dengan $r_{\text {tabel }}$ maka butir dikatakan valid. Dengan $\mathrm{N}=30$ diperoleh nilai $r_{\text {tabel }}$ sebesar 0,361 . $N$ amun menurut azwar bila $r_{\text {hitung }}>0.3$ maka pengujian indikator dinyatakan valid, bila $r_{\text {hitung }}<0.3$ maka pengujian indikator tidak valid (2001: 231). Sedangkan untuk uji reliabilitas dilakukan dengan membandingkan nilai cronbach alfa dengan batas minimal yang diakui yaitu 0,6.

Analisis yang digunakan dalam penelitian ini adalah analisis deskriptif menggunakan teknik analisis faktor (Principal Component Analysis). Analisis faktor digunakan untuk membantu mencari factor-faktor utama yang paling mempengaruhi variabel dependen dari serangkaian uji yang dilakukan atas serangkaian variabel independen sebagai faktornya (Santoso, 2006:13). Dalam hal ini peneliti hendak menentukan sejumlah kompetensi/ ketrampilan yang paling banyak dibutuhkan untuk membentuk lulusan PGRA UIN Maulana Malik Ibrahim Malang. Untuk analisis faktor, sejumlah asumsi berikut harus dipenuhi: 1) Korelasi antarvariabel independen, 2) Korelasi Parsial, 3) Pengujian seluruh matriks korelasi (korelasi antar variabe) (Santoso, 2006: 13)

\section{Paparan Data dan Pembahasan}

Dalam penelitian ini dilakukan survei pada lembaga RA/BA/TA di wilayah kota Malang dan beberapa lembaga di sekitarnya untuk mengetahui kebutuhan lembaga RA/BA/TA dalam rangka melengkapi profil lulusan yang diharapkan oleh masyarakat (lembaga pendidikan formal). Jumlah RA/BA/TA yang ada di Kota Malang sejumlah 90 lembaga. Responden yang mengembalikan angket berjumlah 100 .

\section{Analisis Kebutuhan Kompetensi Pelengkap}

Dalam penelitian yang dilakukan melalui analisis faktor, peneliti mencoba untuk mencari faktor-faktor mana yang paling utama dibutuhkan oleh masyarakat pengguna (dalam hal ini lembaga RA ) yang perlu dimiliki oleh seorang lulusan PGRA.

Untuk analisis faktor, sebagaimana telah dikemukakan sebelumnya sejumlah asumsi berikut harus dipenuhi: 1) Korelasi antarvariabel independen, 2) Korelasi Parsial, 3) Pengujian seluruh matriks korelasi (korelasi antar variabel). Hasil pengujian menunjukkan bahwa analisis faktor dapat dilakukan/dilanjutkan karena uji asumsi telah terpenuhi. Hal ini ditunjukkan hasil uji korelasi antarvariabel independen ada pada output KMO and Bartlett's Test, sebagai berikut: 
Tabel 1

\begin{tabular}{|l|l|r|}
\hline \multicolumn{2}{|c|}{ KMO and Bartlett's Test } \\
\hline Kaiser-M eyer-O Ikin M easure of Sampling A dequacy. & .883 \\
\hline Bartlett's Test of Sphericity & A pprox. Chi-Square & 3246.738 \\
\cline { 2 - 3 } & Df & 325 \\
\cline { 2 - 3 } & Sig. & .000 \\
\hline
\end{tabular}

Nilai KMO and Bartlett's Test untuk korelasi antarvariabel yang diinginkan adalah >0,5. Signifikansi penelitian adalah 0,00. Dari hasil di atas diperoleh nilai KMO yang lebih besar dari 0,5. Sementara itu, signifikansi yang dihasilkan dari Bartlett's Test of Sphericity sebesar 0,000. Dengan hasil pada tabel di atas, maka dapat dikatakan bahwa variabel yang digunakan memungkinkan untuk dilakukan analisis lebih lanjut.

Selanjutnya, asumsi yang kedua untuk mengetahui apakah variabel - variabel secara parsial layak untuk dianalisis dan tidak dikeluarkan dalam pengujian ditunjukkan oleh nilai M SA (M easure of Sampling A dequacy). $\mathrm{H}$ asil analisis menunjukkan nilai M SA variabel bernilai di atas 0,5 yakni: H afalan Surat-surat Pendek sebesar 0.926, Kemampuan Baca Tulis A I-Qur'an sebesar 0.874, Praktik Ibadah Sehari-hari sebesar 0.910, Doa-doa Harian sebesar 0.912, ketrampilan seni rupa sebesar 0.868 , Ketrampilan seni suara dan musik sebesar 0.908 , ketrampilan seni tari sebesar 0.894, Komunikasi Verbal sebesar 0.960, Kemampuan Bahasa Inggris sebesar 0.880, Komunikasi Tertulis sebesar 0.925, Memimpin Tim sebesar 0.939, Teamwork (Bekerja dalam tim) sebesar 0.913, Publik Speaking sebesar 0.922, Kemampuan IT sebesar 0.922, Kemampuan Adaptasi sebesar 0.856, Kreatifitas sebesar 0.799, Pengendalian Emosi sebesar 0.844, M enunjukkan Kasih Sayang sebesar 0.821, Pantang M enyerah sebesar 0.827, Percaya Diri sebesar 0.882, Disiplin sebesar 0.910, Inisiatif sebesar 0.951, Bekerja Keras sebesar 0.848 , M otivasi sebesar 0.851 , dan Tekun sebesar 0.888 . Berdasarkan hasil MSA tersebut di atas, maka dapat dipastikan seluruh komponen dapat dianalisis lebih lanjut karena masingmasing nilainya $>0,5$.

U paya penelitian ini adalah guna menentukan prioritas kebutuhan pasar terhadap kompetensi lulusan PGRA yang diharapkan lembaga pengguna. Penelitian ini juga ingin mengetahui apakah komponen-komponen pada setiap analisis kebutuhan ini bisa dikelompokkan ke dalam satu atau beberapa faktor. Langkah selanjutnya adalah melakukan analisis faktor. Hasil analisis faktor meliputi: 1) Penjelasan variabel oleh faktor, 2) Faktor yang mungkin terbentuk, 3) Faktor Loading

a. Penjelasan Variabel Oleh Faktor

Hasil analisis ini menjelaskan seberapa besar faktor yang nantinya terbentuk mampu menjelaskan variabel. Dari hasil analisis data dengan menggunakan program SPSS ditunjukkan oleh output berikut:

Tabel 5

\begin{tabular}{|l|c|c|}
\hline \multicolumn{3}{|c|}{ Communalities } \\
\hline & Initial & Extraction \\
\hline H afalan Surat Pendek & 1.000 & .686 \\
\hline Baca Tulis AI Qur'an & 1.000 & .648 \\
\hline Ibadah & 1.000 & .782 \\
\hline Doa H arian & 1.000 & .728 \\
\hline
\end{tabular}




\begin{tabular}{|l|l|l|}
\hline Seni Rupa & 1.000 & .903 \\
\hline Seni M usik & 1.000 & .892 \\
\hline Seni Tari & 1.000 & .868 \\
\hline Komunikasi Verbal & 1.000 & .663 \\
\hline Kemampuan Bahasa Inggris & 1.000 & .722 \\
\hline Kemampuan Bahasa Arab & 1.000 & .735 \\
\hline Komunikasi Tertulis & 1.000 & .661 \\
\hline Memimpin Tim & 1.000 & .761 \\
\hline Teamwork & 1.000 & .690 \\
\hline Publik Speaking & 1.000 & .661 \\
\hline Kemampuan IT & 1.000 & .412 \\
\hline Kemampuan adaptasi & 1.000 & .470 \\
\hline Kreativitas & 1.000 & .658 \\
\hline Pengendalian Emosi & 1.000 & .892 \\
\hline M enunjukkan Kasih Sayang & 1.000 & .827 \\
\hline Pantang M enyerah & 1.000 & .791 \\
\hline Percaya Diri & 1.000 & .796 \\
\hline Disiplin & 1.000 & .818 \\
\hline Inisiatif & 1.000 & .723 \\
\hline Bekerja Keras & 1.000 & .847 \\
\hline M otivasi & 1.000 & .866 \\
\hline Tekun & 1.000 & .853 \\
\hline Extraction M ethod: Principal Component Analysis. & & \\
\hline
\end{tabular}

Keeratan hubungan variabel setiap komponen pada tabel 5 terhadap faktor yang terbentuk ditunjukkan pada kolom extraction. A rtinya hubungan setiap variabel terhadap faktor yang terbentuk cukup erat ditunjukkan oleh besarnya prosentase kontribusinya di atas 0.5.

b. Faktor yang mungkin terbentuk

Tahap selanjutnya adalah menentukan seberapa banyak faktor yang mungkin terbentuk. Untuk menjelaskan tahapan ini dapat dilihat pada output total variance explained berikut ini :

Tabel 6

\begin{tabular}{|c|c|c|c|c|c|c|c|c|c|}
\hline \multicolumn{9}{|c|}{ Total Variance Explained } \\
\hline \multirow{2}{*}{ Component } & \multicolumn{3}{|c|}{ Initial Eigenvalues } & \multicolumn{2}{|c|}{$\begin{array}{c}\text { Extraction Sums of Squared } \\
\text { Loadings }\end{array}$} & \multicolumn{3}{|c|}{$\begin{array}{c}\text { Rotation Sums of Squared } \\
\text { Loadings }\end{array}$} \\
\cline { 2 - 11 } & Total & $\begin{array}{c}\% \text { of } \\
\text { Variance }\end{array}$ & $\begin{array}{c}\text { Cumulative } \\
\%\end{array}$ & Total & $\begin{array}{c}\% \text { of } \\
\text { Variance }\end{array}$ & $\begin{array}{c}\text { Cumulative } \\
\%\end{array}$ & Total & $\begin{array}{c}\% \text { of } \\
\text { V ariance }\end{array}$ & $\begin{array}{c}\text { Cumulative } \\
\%\end{array}$ \\
\hline 1 & 14.955 & 57.520 & 57.520 & 14.955 & 57.520 & 57.520 & 8.809 & 33.883 & 33.883 \\
\hline 2 & 3.082 & 11.852 & 69.372 & 3.082 & 11.852 & 69.372 & 5.869 & 22.572 & 56.454 \\
\hline 3 & 1.316 & 5.062 & 74.434 & 1.316 & 5.062 & 74.434 & 4.675 & 17.980 & 74.434 \\
\hline 4 & .837 & 3.220 & 77.654 & & & & & & \\
\hline 5 & .801 & 3.079 & 80.733 & & & & & & \\
\hline
\end{tabular}




\begin{tabular}{|c|c|c|c|l|l|l|l|l|l|}
\hline 6 & .739 & 2.842 & 83.575 & & & & & & \\
\hline 7 & .602 & 2.316 & 85.891 & & & & & & \\
\hline 8 & .501 & 1.927 & 87.818 & & & & & & \\
\hline 9 & .468 & 1.799 & 89.617 & & & & & & \\
\hline 10 & .413 & 1.590 & 91.207 & & & & & & \\
\hline 11 & .367 & 1.410 & 92.617 & & & & & & \\
\hline 12 & .324 & 1.247 & 93.864 & & & & & & \\
\hline 13 & .276 & 1.060 & 94.925 & & & & & & \\
\hline 14 & .239 & .919 & 95.843 & & & & & & \\
\hline 15 & .197 & .759 & 96.602 & & & & & & \\
\hline 16 & .194 & .746 & 97.348 & & & & & & \\
\hline 17 & .146 & .562 & 97.910 & & & & & & \\
\hline 18 & .133 & .510 & 98.420 & & & & & & \\
\hline 19 & .114 & .437 & 98.856 & & & & & & \\
\hline 20 & .086 & .331 & 99.187 & & & & & & \\
\hline 21 & .067 & .257 & 99.444 & & & & & & \\
\hline 22 & .043 & .167 & 99.611 & & & & & & \\
\hline 23 & .039 & .151 & 99.762 & & & & & & \\
\hline 24 & .033 & .127 & 99.889 & & & & & & \\
\hline 25 & .016 & .063 & 99.951 & & & & & & \\
\hline 26 & .013 & .049 & 100.000 & & & & & & \\
\hline & & & & & & & & & \\
\hline
\end{tabular}

Tabel di atas menjelaskan bahwa semua variabel di atas dapat diekstrak dalam 3 faktor. $\mathrm{Hal}$ ini ditunjukkan pada kolom nilai eigenvalues dimana untuk menentukan berapa komponen/faktor yang dipakai agar dapat menjelaskan keragaman total, maka komponen dengan eigenvalue $>1$ adalah komponen yang dipakai. Ketiga faktor tersebut sudah cukup mewakili keragaman variabel - variabel yang ada di dalamnya. Kolom cumulative \% menunjukkan persentase kumulatif varians yang dapat dijelaskan oleh faktor. Besarnya keragaman yang mampu diterangkan oleh Faktor 1 sebesar 57,520\%, sedangkan keragaman yang mampu dijelaskan oleh Faktor 1 dan 2 sebesar 69,372\%, dan keragaman yang mampu dijelaskan oleh factor 1, 2 dan 3 adalah sebesar 74.434\%. Ketiga faktor mampu menjelaskan keragaman total sebesar $74,434 \%$. Berdasarkan nilai eigenvalue ketiga faktor yang lebih dari 1 dan besarnya persentase kumulatif kedua faktor sebesar $74,434 \%$, dapat disimpulkan bahwa kedua faktor sudah cukup mewakili keragaman variabel - variabel di dalamnya.

\section{c. Faktor Loading}

$\mathrm{H}$ asil analisis pada tahapan ini adalah menentukan masing-masing variabel independen yang akan masuk ke dalam faktor. Pada analisis yang telah dilakukan, tabel Component M atrix secara langsung memberikan informasi tentang variabel-variabel yang memang dimasukkan ke dalam 3 faktor tersebut dan ditampilkan secara berurutan sebagaimana tampak pada tabel 7 . 
Tabel 7

\section{Rotated Component Matrix}

\begin{tabular}{|l|r|r|r|}
\hline & \multicolumn{3}{|c|}{ Component } \\
\hline & 1 & 2 & 3 \\
\hline Pengendalian Emosi & .876 & .219 & .276 \\
\hline M enunjukkan Kasih Sayang & .860 & .238 & .178 \\
\hline Percaya Diri & .857 & .175 & .175 \\
\hline Bekerja Keras & .851 & .262 & .233 \\
\hline M otivasi & .848 & .280 & .263 \\
\hline Disiplin & .847 & .260 & .178 \\
\hline Pantang M enyerah & .846 & .190 & .195 \\
\hline Tekun & .840 & .234 & .304 \\
\hline Inisiatif & .798 & .216 & .198 \\
\hline Kreativitas & .696 & .259 & .326 \\
\hline Kemampuan adaptasi & .616 & .266 & .141 \\
\hline Kemampuan IT & .482 & .386 & .177 \\
\hline Kemampuan Bahasa Arab & .192 & .785 & .284 \\
\hline Teamwork & .303 & .760 & .144 \\
\hline Kemampuan Bahasa Inggris & .334 & .742 & .243 \\
\hline M emimpin Tim & .401 & .737 & .237 \\
\hline Komunikasi Tertulis & .139 & .716 & .359 \\
\hline Publik Speaking & .458 & .671 & .040 \\
\hline Komunikasi Verbal & .205 & .615 & .492 \\
\hline Ibadah & .222 & .350 & .781 \\
\hline H afalan Surat Pendek & .352 & .073 & .746 \\
\hline Seni Rupa & .227 & .548 & .743 \\
\hline Baca Tulis AI Qur'an & .371 & .170 & .694 \\
\hline Seni M usik & .196 & .611 & .693 \\
\hline Seni Tari & .371 & .549 & .655 \\
\hline Doa H arian & .200 & .577 & .596 \\
\hline
\end{tabular}

Extraction M ethod: Principal Component A nalysis.

Rotation M ethod: V arimax with Kaiser Normalization.

a. Rotation converged in 6 iterations.

Pada tabel memberikan informasi tentang factor loading di mana factor yang terbentuk adalah 3 yaitu Faktor 1, Faktor 2 dan Faktor 3. Kemudian setiap variabel akan dimasukkan ke dalam masing-masing faktor yang terbentuk terbentuk. Tabel 6 menunjukkan besarnya korelasi tiap variabel dalam setiap faktor yang terbentuk. Penentuan input variabel ke faktor tertentu mengikuti besarnya korelasi antara variabel dalam faktor, yaitu kepada yang korelasinya besar. Sehingga terbentuk seperti berikut: 
1) Faktor 1 terdiri dari : Pengendalian Emosi, Menunjukkan Kasih Sayang, Percaya Diri, Bekerja Keras, Motivasi, Disiplin, Pantang Menyerah, Tekun, Inisiatif, Kreativitas, Kemampuan adaptasi, Kemampuan IT

2) Faktor 2 terdiri dari : Kemampuan Bahasa Arab, Teamwork, Kemampuan Bahasa Inggris, M emimpin Tim, Komunikasi Tertulis, Publik Speaking, Komunikasi Verbal

3) Faktor 3 terdiri dari : Ketrampilan Seni Suara, Keterampilan Seni Tari, Hafalan Surat Pendek, Keterampilan Seni Rupa, I badah, D oa Harian, Baca Tulis A Iqur'an.

\section{Pembahasan H asil Penelitian}

Persaingan dunia kerja semakin lama semakin tajam terutama untuk menghadapi Masyarakat Ekonomi Asean di mana dibutuhkan tenaga kerja yang benar-benar profesional. Hal ini tentu saja menuntut kesiapan dari lulusan sebuah perguruan tinggi untuk masuk di kawasan M asyarakat Ekonomi Asean. Hal ini sejalan dengan Strategi Pendidikan Tinggi Jangka Panjang 2003 - 2010 (Dirjen Dikti, 2004) yang dirumuskan oleh Depdiknas secara jelas menyebutkan bahwa peran pendidikan tinggi dalam peningkatan daya saing bangsa sangat vital mengingat tingkat persaingan sumber daya manusia (SDM) di pasar kerja nasional maupun internasional terus meningkat seiring dengan peningkatan pemanfaatan ilmu pengetahuan dan teknologi baru pada berbagai bidang dunia usaha, serta kebutuhan tingkat profesionalisme (knowledge, hard skill, soft skill) yang semakin tinggi.

M eskipun lulusan PGRA mungkin tidak banyak namun jika lulusan PGRA tidak siap dan tidak sesuai dengan kebutuhan pasar, lembaga yang menjadi tujuan lulusan PGRA tentunya akan berpaling dan menganggap lulusan PGRA ataupun non PGRA sama sekali tidak berbeda. Oleh karena itu lulusan harus dilengkapi dengan berbagai keterampilan yang akan melengkapi mereka sebagai lulusan PGRA yang sesuai kebutuhan pasar dan tentu memiliki ciri khas tersendiri yang menunjukkan identitas lembaga yang menghasilkannya, dalam hal ini jurusan PGRA FITK UIN M aulana M alik Ibrahim Malang.

Keterampilan yang perlu dimiliki oleh mahasiswa PGRA UIN Maulana Malik Ibrahim $M$ alang berdasarkan prioritas kebutuhannya adalah sebagai berikut:

1. Faktor 1 yaitu faktor yang terdiri dari keterampilan-keterampilan yang berkaitan dengan keterampilan inter personal yakni Pengendalian Emosi, M enunjukkan Kasih Sayang, Percaya Diri, Bekerja Keras, Motivasi, Disiplin, Pantang Menyerah, Tekun, Inisiatif, Kreativitas, Kemampuan adaptasi, Kemampuan IT

2. Faktor 2 yaitu faktor yang terdiri dari keterampilan yang berkaitan dengan keterampilan antar personal yaitu Kemampuan Bahasa Arab, Teamwork, Kemampuan Bahasa Inggris, M emimpin Tim, Komunikasi Tertulis, Publik Speaking, Komunikasi V erbal

3. Faktor 3 terdiri dari keterampilan yang berkaitan dengan keahlian teknis yaitu Ibadah, Hafalan Surat Pendek, Keterampilan Seni Rupa, Baca Tulis Alqur'an, Keterampilan Seni Suara, Keterampilan Seni Tari, Doa Harian.

\section{Kesimpulan dan Saran}

Kompetensi Pelengkap/Keterampilan yang perlu dimiliki oleh mahasiswa PGRA UIN Maulana Malik Ibrahim Malang berdasarkan prioritas kebutuhannya adalah sebagai berikut: (1) Faktor 1 yaitu faktor yang terdiri dari keterampilan-keterampilan yang berkaitan dengan keterampilan inter personal, yakni: pengendalian emosi, menunjukkan kasih sayang, percaya diri, bekerja keras, motivasi, disiplin, pantang menyerah, tekun, inisiatif, kreativitas, kemampuan adaptasi, 
kemampuan IT. (2) Faktor 2 yaitu faktor yang terdiri dari keterampilan yang berkaitan dengan keterampilan antar personal, yaitu: kemampuan bahasa Arab, teamwork, kemampuan bahasa Inggris, memimpin tim, komunikasi tertulis, publik speaking, dan komunikasi verbal. (3) Faktor 3 terdiri dari keterampilan yang berkaitan dengan keahlian teknis, yaitu: ibadah, hafalan surat pendek, keterampilan seni rupa, baca tulis al-Qur'an, keterampilan seni suara, keterampilan seni tari, doa harian.

Menghadapi tantangan globalisasi berupa kompetisi di dunia kerja membutuhkan kesiapan yang matang bagi mahasiswa begitu ia lulus dari perguruan tinggi. Tuntutan-tuntutan kompetensi yang harus terpenuhi merupakan PR yang harus dipikirkan oleh program studi yang terkait. Penelitian yang berkelanjutan merupakan salah satu langkah tindak lanjut untuk terus mengembangkan dan memperoleh hasil yang lebih maksimal. Pembenahan-pembenahan perlu dilakukan untuk menjawab tantangan-tantangan tersebut. Kegiatan-kegiatan evaluasi dilakukan secara terus menerus perlu dilakukan menyesuaikan dinamika yang ada di lapangan. Pembenahan tidak cukup hanya dilakukan oleh program studi yang terkait. Butuh dukungan dari seluruh civitas akademika. M enjalin silaturrahmi dan komunikasi yang baik adalah jalan yang terbaik.

\section{Referensi}

A rikunto, Suharsimi (2010). Evaluasi Program Pendidikan. Jakarta: Bumi Aksara. (2010), Prosedur Penelitian: Suatu Pendekatan Praktek. Jakarta: Rineka Cipta.

Azwar, S. (2012). Reliabilitas dan V aliditas. Yogyakarta: Pustaka Pelajar.

Guyette, Susan (1983). Community-Based: Research A Handbook For Native Americans, California: Administration For Native Americans, Office Of H uman Development Services, Department Of $\mathrm{H}$ ealth And Human Services.

Kurniawan Tatang, May 16, 2011, Evaluasi Need Assesment Dalam Pembelajaran Teknologi Informasi Pendidikan Kejuruan, $\mathrm{Http}: / / T$ atangkurniawan77.W ordpress.Com/2011/05/16/ Evaluasi-N eed-Assessment/

Rossett, A., Arwady, J.W. (1992). Training Needs assessment. New Jersey: Educational Technological Publications.

Teichler, U. (1999). Research on the relationship between higher education and the world of work: past achievements, problems and new challenges. Higher Education Vol 38: 169-190.

Yorke, M and Knight P. (2006). Curricula for economic and social gain. Higher Education 2006 Vol 51: 565-568.

Yorke, M and Knight P. (2003). A ssessment, Learning and Employability. O pen University Press. Berkshire England. 